\title{
Microwave Irradiation-assisted RNA Extraction from Woody Tissues for Plant Virus Detection
}

\author{
Thanh Van Duong, Dong-Il Shin and Hee-Sung Park* \\ Department of Biotechnology, Catholic University of Daegu, Kyungsan 712-702, Korea \\ (Received on July 7, 2010; Accepted on August 3, 2010)
}

\begin{abstract}
Plant tissue homogenization using a mortar or mechanical equipment has been the preferred method for obtaining high yields of total RNA; this method, however, is both time-consuming and expensive. Additionally, homogenization may generate excessive endogenous RNases, polyphenolics, and other substances that reduce the quality and quantity of RNA. In this study, we describe the microwave irradiation-assisted RNA extraction (MIRE) technique which, without tissue disruption and homogenization, allows for the cost-effective and rapid generation of intact RNA from apple cane shavings and the reliable detection of apple virus by RT-PCR.
\end{abstract}

Keywords: microwave irradiation, RNA extraction, RT$\mathrm{PCR}$, plant virus

RT-PCR is extensively employed in the detection of plant viruses with RNA genomes, due to the reliability and sensitivity of the technique; however, this method depends heavily on the quality of the RNA used. Currently, RT-PCR is considered an important technique for the detection of pathogenic apple viruses. One of the challenges of RT-PCR is tissue homogenization, which consumes a great deal of time and labor. Although tissue disruption and homogenization is very necessary for the acquisition of sufficient quantities of RNA, too many substances that hinder the performance of RT-PCR are inevitably produced. To address this, guanidine thiocyanate or guanidine-HCl, PVP-40 and mercaptoethanol can be incorporated into the RNA extraction procedure using plant tissues (James, 1999; John, 1992).

Microwave irradiation is a useful tool in mRNA studies involving in situ hybridization and in situ RT-PCR using animal and human tissues (Besancon et al., 2006; Ekuni et al., 2006; McMahon and McQuaid, 1996). However, microwave irradiation has not been previously considered for use in the extraction of RNA directly from sample tissues. This may be due, in particular, to RNA's vulnerability to oxidation under high temperature condition. This paper

\footnotetext{
*Corresponding author.

Phone) +82-53-850-3245, FAX) +82-53-850-3168

E-mail)hspark@cu.ac.kr
}

describes the use of microwave irradiation as a tool for the direct extraction of total RNA from apple cane tissues. Without homogenizing apple cane tissues, microwave irradiation can rapidly generate intact total RNA for use in RT-PCR-based apple virus diagnosis.

Apple stem grooving virus (ASGV) (Hirata et al., 2003) is one of the apple viruses commonly found in important commercial apple cultivars (Campbell, 1963). For the routine diagnosis of ASGV, the apple cane tissues were disrupted and homogenized using tissue-lysing equipment in our laboratory. Tissue samples were obtained from mixed cultivars of Malus domestica from a local field during winter.

RNA extraction methods. Total RNA was isolated via a silica gel-based method (Menzel et al., 2002) with some modifications. Cane shavings $(100 \mathrm{mg})$ prepared with a pencil sharpener were placed into $2 \mathrm{ml}$ cap tubes containing steel beads ( $2 \mathrm{~mm}$ diameter) filling one-third of the tube and $1 \mathrm{ml}$ of extraction buffer [4 $\mathrm{M}$ guanidine thiocyanate, $0.2 \mathrm{M}$ sodium acetate (pH 5.0), 25 mM EDTA, 2.5\% PVP40]. For tissue homogenization, TissueLyser II (Qiagen, Germany) was employed for $5 \mathrm{~min}$ at a frequency of 30 cycles/s. The homogenates were then centrifuged for 10 min at $12,000 \mathrm{rpm}, 500 \mu \mathrm{l}$ of supernatant was transferred to a new tube, $100 \mu \mathrm{l}$ of $10 \%$ SDS was added for $10 \mathrm{~min}$ at $70^{\circ} \mathrm{C}$, the mixture was centrifuged at $12,000 \mathrm{rpm}$ for $15 \mathrm{~min}$ at $4^{\circ} \mathrm{C}$, and $300 \mu \mathrm{l}$ of the supernatant was transferred to a silica gel column (Genclean column ${ }^{\mathrm{TM}}$, Generay Biotech, USA) fit onto the block connected to a vacuum pump. After the addition of $300 \mu \mathrm{l}$ of $6 \mathrm{M} \mathrm{NaI}$ solution and $150 \mu \mathrm{l}$ of ethanol for $10 \mathrm{~min}$, vacuum filtration was applied for RNA capture, the column was washed twice with wash buffer [10 mM Tris-HCl (pH 7.5), 0.05 mM EDTA, $50 \mathrm{mM}$ $\mathrm{NaCl}, 50 \%$ ethanol], and then finally washed with $75 \%$ ethanol. $50 \mu \mathrm{l}$ of DEPC water was added to the column for 10 min and RNA was collected via 1 min of centrifugation at $10,000 \mathrm{rpm}$. Total RNA integrity was confirmed via agarose gel electrophoresis.

Reverse transcription and polymerase chain reaction (RT-PCR). In order to amplify the 273-bp cDNA fragment of ASGV, RT-PCR was conducted via reverse transcription 


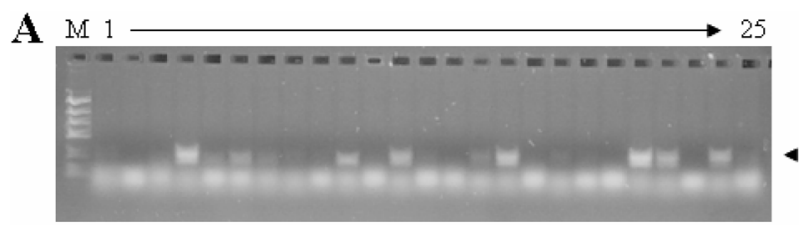

B

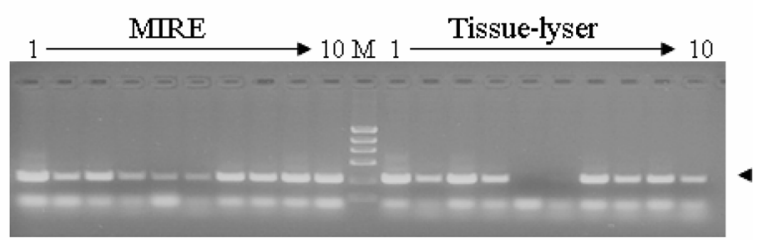

C

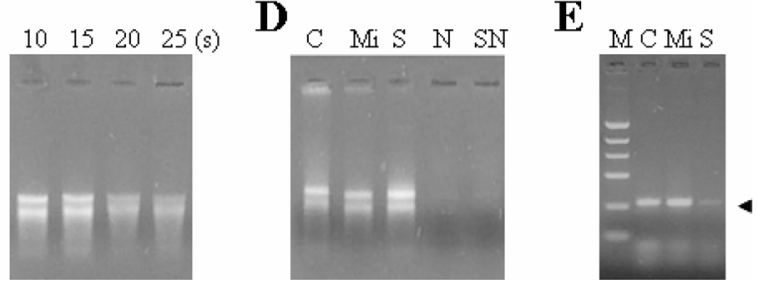

Fig. 1. Total RNA from apple cane shavings and RT-PCR for ASGV detection. A: the RT-PCR results are presented for 25 among 200 apple cane tissue samples tested. Total RNA from tissue homogenates was amplified via RT-PCR and resolved via $2 \%$ agarose gel electrophoresis. The arrow indicates $273 \mathrm{bp}$ ASGV PCR products. M means a 250 bp DNA size marker. B: RT-PCR products (arrow) for ASGV, each of 10 ASGV-positive apple hosts was used for both MIRE and Tissue-lyser (as a control) procedures. On the right side, samples 5 and 6 were in fact attributed to the absence of RNA (data not shown). C: the total RNAs derived from MIRE for 10 to $25 \mathrm{~s}$ were monitored via $1 \%$ agarose gel electrophoresis using TAE buffer. RNA samples were heated for $5 \mathrm{~min}$ at $70^{\circ} \mathrm{C}$ before loading. D: $2 \%$ agarose gel electrophoresis shows total RNAs derived from the procedures of tissue-lyser (C), MIRE (Mi), MIRE/no-SDS treatment (S), MIRE/no-NaI treatment $(\mathrm{N})$ and MIRE/no-SDS and NaI treatment (SN). E: Total RNAs from C, Mi and S were tested for RTPCR.

(30 min, $42^{\circ} \mathrm{C}$ ), denaturation $\left(95^{\circ} \mathrm{C}, 5 \mathrm{~min}\right), 34$ cycles of PCR $\left(94{ }^{\circ} \mathrm{C}, 30 \mathrm{sec} ; 48{ }^{\circ} \mathrm{C}, 30 \mathrm{sec} ; 72^{\circ} \mathrm{C}, 1 \mathrm{~min}\right)$ and a final extension $\left(72^{\circ} \mathrm{C}, 5 \mathrm{~min}\right)$. The reaction mixture $(50 \mathrm{ml}$ in total) contained $5 \mu \mathrm{l}$ of RNA extract, $7.5 \mathrm{ml}$ of $10 \mathrm{x}$ PCR buffer, $0.5 \mu \mathrm{l}$ of $25 \mathrm{mM} \mathrm{MgCl}, 0.5 \mathrm{ml}$ of $10 \%$ Tween-20, $1.0 \mu \mathrm{l}$ of $10 \mathrm{mM}$ dNTP, $0.05 \mu \mathrm{l}$ AMV reverse transcriptase, $1.0 \mu \mathrm{l}$ of Taq polymerase, and $0.7 \mu \mathrm{l}$ of each primer (forward 5'GCCACTTCTAGGCAGAACTCTTTGAA3', reverse 5'AACCCCTTTTTGTCCTTCAGTACGAA3'). Fig. 1 (A) showed some of the results used to screen ASGVinfected apple hosts.

\section{Microwave irradiation-assisted RNA extraction (MIRE).}

The plant virus can spread to adjacent cells via the plasmodesmata and can travel a significant distance through the vascular structure (Lazarowitz and Beachy, 1999). This led us to the notion that microwave irradiation might be capable of releasing extracellular ASGV from submerged cane tissues. So, using a microwave oven for home use (Model MR-202FC, $2.45 \mathrm{GH}, 700 \mathrm{~W}$; LG Electronics, Korea), highest-power function was tested for up to $30 \mathrm{~s}$ to $100 \mathrm{mg}$ of ASGV-positive cane shavings submerged in $1.5 \mathrm{ml}$ of extraction buffer in $10 \mathrm{ml}$ glass tubes. Clear tissue extracts were employed for RNA isolation and RT-PCR as described above. The results are shown in Fig. 1(B). Surprisingly, amplified ASGV cDNA fragments were clearly detected from all 10 independent ASGV-positive tissues. Microwave irradiation applied for 10-20 s was determined to be quite sufficient, but longer irradiation (25-30 s) resulted in excessive evaporation or tissue burning. Additionally, MIRE was shown to be effective only in combination with the buffer containing guanidine thiocyanate. Distilled water or buffer without guanidine thiocyanate proved ineffective, implying that the protein denaturant was an important factor in successful MIRE. Still, the integrity of $6.5 \mathrm{~kb}$ ASGV RNA remained a matter of great concern because RNA breakage, possibly caused by microwave radiation, might falsify the results. Another concern was the scarcity of extracellular ASGV, in spite of its intracellular abundance. However, microwave irradiation, did, in fact, effectively induce total RNA release as shown in Fig. 1(C). High-integrity total RNA (0.5-0.7 $\mu \mathrm{g} / 100 \mathrm{mg}$ tissue) could be generated simply by the application of 10 to $15 \mathrm{~s}$ of microwave irradiation. After 20 to $25 \mathrm{~s}$ of irradiation, the quantity of total RNA was reduced slightly, but did not affect the accuracy of ASGV diagnosis via RT-PCR (data not shown). After $30 \mathrm{~s}$ of irradiation, the extraction buffer was almost completely evaporated and the sample tissues were partially scorched. Meanwhile, SDS appeared not to be required for RNA extraction as shown in Fig. 1(D), even though the PCR product density was reduced slightly as shown in Fig. 1(E). This meant that only a one-time centrifugation was required for the final step of RNA collection, thereby enabling high-throughput RNA isolation in our laboratory. In conclusion, the boiling of sliced apple cane tissues using 10-15 s of microwave irradiation could efficiently release intact total RNA, as well as putative extracellular ASGV.

Thus far, microwaves have been employed as a supplemental tool for the analysis of mRNA expression in animal tissues (Besancon et al., 1995; Ekuni et al., 2006), and as a tool for the direct and rapid extraction of DNA from formalin-fixed paraffin-embedded tissues (Shia et al., 2002; Tabanifar et al., 2008), soil microorganisms (Picard et al., 1992) and barley grains (Saini et al., 1999). In this study, despite the instability of RNA upon exposure to extreme heat, the application of microwave heating to submerged apple cane 
tissues was shown to be excellent for the extraction of total RNA with high integrity, substantially simplifying the RNA isolation procedure. The use of MIRE may be transferable, allowing for the diagnosis of other plant viruses.

\section{References}

Besancon, B., Bencsik, A., Voutsinos, B., Belin, M. F. and FevreMontange, M. 1995. Rapid in situ hybridization using digoxigenin probe and microwave oven. Cell Mol. Biol. 41:975-977.

Campbell, A. I. 1963. The effect of some latent virus infections on the growth and cropping of apples. J. Hort. Sci. 38:15-19.

Ekuni, D., Firth, J. D. and Putnins, E. E. 2006. RNA integrity and in situ RT-PCR in dento-alveolar tissues after microwave accelerated demineralization. Arch. Oral Biol. 51:164-169.

Hirata, H., Lu, X., Yamaji, Y., Kagiwada, S., Ugaki, M. and Namba, S. 2003. A single silent substitution in the genome of Apple stem grooving virus causes symptom attenuation. $J$. Gen. Virol. 84:2579-2583.

James, D. 1999. A simple and reliable protocol for the detection of apple stem grooving virus by RT-PCR and in a multiplex PCR assay. J. Virol. Methods. 83:1-9.

John, M. E. 1992. An efficient method for isolation of RNA and DNA from plants containing polyphenolics. Nucleic Acids Res. 20:2381.

Lazarowitz, S. G. and Beachy, R. N. 1999. Viral movement pro- teins as probes for intracellular and intercellular trafficking in plants. Plant Cell. 11:535-548.

McMahon, J. and McQuaid, S. 1996. The use of microwave irradiation as a pretreatment to in situ hybridization for the detection of measles virus and chicken anaemia virus in formalinfixed paraffin-embedded tissue. Histochem. J. 28:157-164.

Menzel, W., Jelkmann, W. and Maiss, E. 2002. Detection of four apple viruses by multiplex RT-PCR assays with coamplification of plant mRNA as internal control. J. Virol. Methods. 99:81-92.

Picard, C., Ponsonnet, C., Paget, E., Nesme, X. and Simonet, P. 1992. Detection and enumeration of bacteria in soil by direct DNA extraction and polymerase chain reaction. Appl. Environ. Microbiol. 58:2717-2722.

Saini, H. S., Shepherd, M. and Henry, R. J. 1999. Microwave extraction of total genomic DNA from barley grains for use in PCR. J. Inst. Brew. 105: 185-190.

Shia, S. R., Cotea, R. J., Wub, L., Liua, C., Datara, R., Shia, Y., Liua, D., Lima, H. and Taylora, C. R. 2002. DNA extraction from archival formalin-fixed, paraffin-embedded tissue sections based on the antigen retrieval principle: heating under the influence of pH. J. Hist. Cyto. 50:1005-1011.

Tabanifar, B., Salehi, R., Asgarani, R., Faghihi, M., Heidarpur, M. and Allame, T. S. 2008. An efficient method for DNA extraction from paraffin wax embedded tissues for PCR amplification of human and viral DNA. Iran. J. Pathol. 3:173-178. 